\title{
What is the Revised Fear Survey Schedule for Children measuring?
}

Citation for published version (APA):

Muris, P. E. H. M., Merckelbach, H. L. G. J., Ollendick, T. H., King, N. J., Meesters, C. M. G., \& van

Kessel, C. (2002). What is the Revised Fear Survey Schedule for Children measuring? Behaviour

Research and Therapy, 40(11)(11), 1317-1326. https://doi.org/10.1016/S0005-7967(02)00007-4

Document status and date:

Published: 01/01/2002

DOI:

10.1016/S0005-7967(02)00007-4

Document Version:

Publisher's PDF, also known as Version of record

\section{Please check the document version of this publication:}

- A submitted manuscript is the version of the article upon submission and before peer-review. There can be important differences between the submitted version and the official published version of record.

People interested in the research are advised to contact the author for the final version of the publication, or visit the DOI to the publisher's website.

- The final author version and the galley proof are versions of the publication after peer review.

- The final published version features the final layout of the paper including the volume, issue and page numbers.

Link to publication

\footnotetext{
General rights rights.

- You may freely distribute the URL identifying the publication in the public portal. please follow below link for the End User Agreement:

www.umlib.nl/taverne-license

Take down policy

If you believe that this document breaches copyright please contact us at:

repository@maastrichtuniversity.nl

providing details and we will investigate your claim.
}

Copyright and moral rights for the publications made accessible in the public portal are retained by the authors and/or other copyright owners and it is a condition of accessing publications that users recognise and abide by the legal requirements associated with these

- Users may download and print one copy of any publication from the public portal for the purpose of private study or research.

- You may not further distribute the material or use it for any profit-making activity or commercial gain

If the publication is distributed under the terms of Article $25 \mathrm{fa}$ of the Dutch Copyright Act, indicated by the "Taverne" license above, 


\title{
What is the Revised Fear Survey Schedule for Children measuring?
}

\author{
P. Muris ${ }^{\text {a,*}}{ }^{\text {, H. Merckelbach a }}{ }^{\text {, T.H. Ollendick }}{ }^{\text {b }}$, N.J. King ${ }^{\text {c }}$, C. Meesters ${ }^{\text {a }}$, \\ C. van Kessel $^{\text {a }}$ \\ a Department of Medical, Clinical, and Experimental Psychology, Maastricht University, P.O. Box 616, 6200 MD \\ Maastricht, The Netherlands \\ ${ }^{\mathrm{b}}$ Child Study Center, Virginia Polytechnic Institute and State University, VA, USA \\ ${ }^{\mathrm{c}}$ Faculty of Education, Monash University, Australia
}

Accepted 30 October 2001

\begin{abstract}
The Fear Survey Schedule for Children-Revised (FSSC-R) is a widely used self-report questionnaire that purports to measure the number of fears and the overall level of fearfulness in children. A number of studies have shown that the ten most common childhood fears can be found on the Danger and Death subscale of the FSSC-R, with upwards of $50 \%$ of children endorsing such fears. However, some researchers (e.g., H. McCathie \& S.H. Spence, 1991; Behaviour Research and Therapy, 29, 495-502) have questioned the validity of these findings, suggesting that these items do not reflect actual childhood fears that children have or experience on a daily or regular basis. Rather, they suggest that children are responding to these fear items as if they were actually occuring to them in the here and now. The current study examined the occurrence of five Danger and Death fears from the FSSC-R (i.e., "Not being able to breathe", "Being hit by a car or truck", "Falling from high places", "Bombing attacks or being invaded", and "Fire or getting burned") in a sample of normal school children aged eight to 12 years $(N=102)$. More specifically, we used three different methods to asses these fears: (1) prevalence as determined by the standard FSSC-R procedure, (2) prevalence as determined by a fear list procedure, and (3) actual occurrence or prevalence of these fears in the past week, as determined by a diary method. Results indicated that while these fears ranked high when using the standard FSSC-R procedure, they were considerably less common when using the fear list procedure, and had a low probability of actual occurrence on a daily basis, as well as possessing a short duration and low intensity. Implications for the assessment of fears and the use of self-report measures like the FSSC-R are briefly discussed. (C) 2002 Elsevier Science Ltd. All rights reserved.
\end{abstract}

Keywords: Fear Survey Schedule for Children-Revised (FSSC-R); Fears of danger and death

\footnotetext{
* Corresponding author. Tel.: +31-43-388-1264; fax: +31-43-367-0968.
}

E-mail address: p.muris@dep.unimaas.nl (P. Muris). 


\section{Introduction}

The Revised version of the Fear Survey Schedule for Children (FSSC-R; Ollendick, 1983) is without doubt the most frequently used self-report questionnaire for assessing fears and fearfulness in youths (Gullone, 1999). The FSSC-R asks children to indicate on a 3-point scale ('none', 'some', 'a lot') how much they fear 80 specific stimuli or situations. Research has shown that the FSSC-R is a reliable instrument in terms of internal consistency (with Cronbach's alphas in the 0.90 range) and temporal stability (with test-retest correlations of about 0.80 ) (for a brief review, see Stallings \& March, 1995). Factor analytic studies have revealed that the FSSC-R contains five factors: 'Fear of Danger and Death' (e.g., "Being hit by a car or truck"), 'Fear of Failure and Criticism' (e.g., "Looking foolish"), 'Fear of the Unknown' (e.g., "Going to bed in the dark"), 'Fear of Small Animals' (e.g., "Snakes"), and 'Medical Fears' (e.g., "Getting an injection from the nurse or doctor"). There is also strong evidence that this factor structure can be generalized across children in the United States (Ollendick, 1983), Australia (Ollendick, King, \& Frary, 1989), England (Ollendick, Yule, \& Ollier, 1991), The Netherlands (Oosterlaan, Prins, Hartman, \& Sergeant, 1995), and Spain (Sandin \& Chorot, 1998). Support for the validity of the FSSC-R comes from two sources. First, FSSC-R scores correlate substantially with other childhood anxiety measures such as the Revised Children's Manifest Anxiety Scale (RCMAS; Reynolds \& Richmond, 1978) and the trait version of the State-Trait Anxiety Inventory for Children (STAIC; Spielberger, 1973) (see Ollendick, 1983; Ollendick, Yule \& Ollier, 1991). Second, the FSSC-R has been found to be useful in differentiating between various types of specific phobias (Weems, Silverman, Saavedra, Pina, \& White Lumpkin, 1999). Altogether, the FSSC-R appears to be a useful measure of childhood fears and fearfulness with sound psychometric properties.

A consistent finding in FSSC-R studies is that the most common fears reported by children can be found on the Danger and Death factor (e.g., King, Hamilton, \& Ollendick, 1988; King, Ollier, Iacuone et al., 1989; Muris, Merckelbach, Meesters, \& Van Lier, 1997b; Ollendick, 1983). That is, children report to be most fearful of events that have to do with physical injury and danger, such as "Not being able to breathe", "Bombing attacks or being invaded", "Being hit by a car or truck", "Fire or getting burned", and "Falling from high places". Although it is evident that these events are threatening and potentially fearful, it seems rather unlikely that normal children are frequently troubled by fear of such events on a daily basis. In McCathie and Spence's (1991; p.495-496) words: "Whereas it is perhaps sensible to suggest that these events would be extremely fear producing if they were to occur, they are not highly probable events. Given such low probability of occurrence, it seems unlikely that children frequently worry about these events or engage in avoidance behaviour in order to prevent their occurrence". These authors suggested that many Danger and Death fear items of the FSSC-R do not assess the frequency of actual fearful behaviour, but rather negative affective responding to the thought of the actual occurrence of these specific events were they to occur.

In order to test this hypothesis, McCathie and Spence (1991) constructed a modified version of the FSSC-R, which they termed the Fear Frequency and Avoidance Survey Schedule for Children (FFASSC). This scale was designed to measure the frequency with which children experience FSSC-R items in terms of worrying or having frightened feelings and thoughts and engaging in avoidance behaviours. The new scale was administered to a sample of 376 normal school children aged seven to 12 years and it was anticipated that children would not display high levels of fearful 
thoughts and avoidance behaviour in relation to these common FSSC-R fears. However, in contrast to McCathie and Spence's (1991) predictions, results indicated that children reported the highest levels of fearful thoughts and avoidance behaviour to exactly those items that were previously identified as the most prevalent fears, namely fears related to danger and death. In a subsequent study, Ollendick and King (1994) investigated in a large sample of 646 Australian adolescents to what extent FSSC-R listed fears interfered with daily life. For this purpose, the authors employed a modified version of the FSSC-R in which adolescents were asked to indicate how much the various fear stimuli and situations interfered with their daily lives. Specifically, they were asked to indicate how much the fear "interferes with your daily activities; that is, how much it prevents you from doing the things you would like to do or feel you should do" (p. 636). A majority of the adolescents $(60 \%)$ reported that the common FSSC-R danger and death fears caused them considerable distress and interfered significantly with their daily activities.

To recap, although the FSSC-R provides valuable information about children's fears and fearfulness, researchers have questioned the validity of children's responses to various items on this survey. The fact that children typically report being highly fearful of danger and death items which, in reality, have an extremely low base rate of occurrence is indeed puzzling. So far, attempts to demonstrate that children are not genuinely troubled by these events have failed, as children report that these events are associated with high levels of fearful thoughts, avoidance behaviour, and interference (McCathie \& Spence, 1991; Ollendick \& King, 1994). It should be noted, however, that these studies have relied on questionnaires that bear a strong resemblance to the FSSC-R. Thus, it is entirely possible that even when children are asked to rate frequencies of fearful thoughts, avoidance behaviour, and/or level of interference for danger and death items, they tend to draw upon their affective responses to the hypothetical occurrences of these stimuli rather than their actual fear response, as suggested by McCathie and Spence (1991).

With these issues in mind, the current study was undertaken. The prevalence of five common FSSC-R fears related to danger and death (i.e., "Not being able to breathe", "Being hit by a car or truck", "Falling from high places", "Bombing attacks or being invaded", and "Fire or getting burned") was examined in detail in a sample of 102 normal school children aged eight to 12 years. More specifically, we assessed (1) the prevalence of the target fears in a FSSC-R based ranking procedure by calculating the percentage of children endorsing 'a lot of fear' to these items, (2) the prevalence of these fears when using a fear list procedure (i.e., children were asked to list the stimuli and situations that they feared in the absence of a list of potential fears such as that provided on the FSSC-R), and (3) the actual occurrence of these fears in the past week, as obtained via a retrospective diary. It was anticipated (a) that the pertinent fears would rank high in a FSSC-R based fear rank order procedure, (b) that these fears would be considerably less prevalent when assessed with a free format list procedure, and (c) that these fears would have a low probability of occurrence in daily life and they would be characterized by low intensities of affect.

\section{Method}

\subsection{Participants}

A sample of 102 children (53 boys and 49 girls) was recruited from two regular primary schools in South-Limburg, The Netherlands. Mean age of the children was 11.3 years $(S D=1.1$; range 8 
to 12 years). The children were primarily Caucasian $(>95 \%)$. Due to school constraints, additional information about the socioeconomic status and family structure of the children was not available to us.

\subsection{Assessment}

\subsubsection{Fear list procedure}

Children were given a blank sheet of paper and asked to write down all stimuli and situations they feared.

\subsection{2. $F S S C-R$}

As mentioned earlier, the FSSC-R is an 80-item self-report questionnaire for assessing fears and fearfulness in children. Children are asked to indicate their level of fear to various stimuli and situations on a 3-point scale: 'none', 'some', 'a lot'. These are scored 1, 2, and 3, respectively, and then summed to yield a total fear score (range: 80-240) and/or factor-based subscale scores.

\subsubsection{Fear calendar}

Children were given a weekly calendar on which they were requested to fill in retrospectively on what days they had been fearful of the five FSSC-R Danger and Death items. For each item, the question was "Have you been fearful of ... in the past week?". When children answered 'Yes' to this question, they were asked to specify how long they were bothered by this fear: $1=$ 'just for a moment', $2=$ 'less than 1 hour', or $3=$ 'for at least one hour' (i.e., fear duration) and to rate the level of fear: $2=$ 'some' or $3=$ ' $a$ lot'. For children who reported that the pertinent fear did not occur, level of fear was scored as $1=$ 'none'.

\subsection{Procedure}

Children first completed the fear list procedure and then filled out the FSSC-R. This took place in the children's classrooms with the teacher and a research assistant present to provide assistance, if necessary, and to ensure confidential and independent responding. Two weeks after the classroom assessments, children completed the fear calendars individually in a separate room at school. A research assistant, under the guidance of the senior author, assisted the children in completion of the diaries.

\section{Results}

\subsection{Prevalence of target fears in a FSSC-R based ranking}

Following previous research (e.g., Ollendick, 1983), a rank order of FSSC-R fears was derived from the percentage of children who endorsed 'a lot' of fear for each stimulus or situation listed 
by the FSSC-R. As can be seen in Table 1, the five target fears (i.e., "Not being able to breathe", "Being hit by a car or truck", "Falling from high places", "Bombing attacks or being invaded", and "Fire or getting burned") were listed in the top ten of the most common fears for these children.

\subsection{Prevalence of target fears when using the fear list procedure}

In the fear list procedure, children mentioned 49 different fears (see Table 2). Four of the five target fears also featured in the fear list ranking, that is, "Bombing attacks/being invaded" (no. 8: war), "Falling from high places" (no. 15: heights), "Being hit by a car or truck" (no. 17: traffic accident), and "Fire/getting burned" (no. 23: fire). Unexpectedly, "Not being able to breathe" was not mentioned by any of the children. Thus, target fears from the FSSC-R were considerably less prevalent and not as highly ranked when assessed with the fear list procedure: only one of them was ranked among the ten most prevalent fears using this method.

\subsection{Prevalence of target fears in daily life}

Analysis of children's fear calendars revealed that the prevalence of target fears in the past week was rather low. Six children $(5.9 \%)$ reported the fear of "Not being able to breathe", 8 $(7.8 \%)$ reported the fear of "Being hit by a car or truck", 3 (2.9\%) reported the fear of "Bombing attacks/being invaded", 7 (6.9\%) reported the fear of "Fire/getting burned", and $12(11.8 \%)$ reported the fear of "Falling from high places". Furthermore, in most cases, children indicated that the duration of these fears was relatively short (i.e., just for a moment) and that the intensity of the fear was rather modest (i.e., some fear) (see Table 3).

Fig. 1 shows percentages of children who endorsed $3=$ 'a lot of fear' to each of the five target fears when using the FSSC-R and the fear calendar scores. Nonparametric sign tests revealed significant differences for all fears: $Z=7.0, P<0.001$ for "Not being able to breathe", $Z=5.6$, $P<0.001$ for "Being hit by a car or truck", $Z=6.9, P<0.001$ for "Bombing attacks/being invaded",

Table 1

The 10 most common FSSC-R ${ }^{\mathrm{a}}$ fears in a sample of 102 children

\begin{tabular}{|c|c|c|c|}
\hline Fear & $M(S D)$ & \multicolumn{2}{|c|}{$\begin{array}{l}\text { Number and } \% \text { endorsing } 3=\text { 'a lot of } \\
\text { fear' }\end{array}$} \\
\hline 1. Not being able to breathe & $2.4(0.6)$ & 51 & 50.0 \\
\hline 2. Bombing attacks/being invaded & $2.4(0.7)$ & 51 & 50.0 \\
\hline 3. Getting a serious disease & $2.2(0.7)$ & 35 & 34.3 \\
\hline 4. Being hit by a car or truck & $2.2(0.7)$ & 34 & 33.3 \\
\hline 5. Falling from a high place & $2.1(0.7)$ & 34 & 33.3 \\
\hline 6. A burglar breaking into our house & $2.2(0.6)$ & 30 & 29.4 \\
\hline 7. Fire/getting burned & $2.1(0.7)$ & 28 & 27.5 \\
\hline 8. Earthquakes & $2.0(0.7)$ & 25 & 24.5 \\
\hline 9. Getting lost in a strange place & $2.0(0.7)$ & 23 & 22.5 \\
\hline 10. Getting an electric shock & $1.9(0.8)$ & 23 & 22.5 \\
\hline
\end{tabular}

\footnotetext{
a FSSC-R=Fear Survey Schedule for Children-Revised.
} 
Table 2

Fear ranking based on free format fear list procedure $(N=102)$

\begin{tabular}{|c|c|c|c|}
\hline \multicolumn{2}{|c|}{ Fear } & \multirow{2}{*}{$\frac{n}{32}$} & \multirow{2}{*}{$\frac{\%}{31.4}$} \\
\hline 1. & Spiders & & \\
\hline 2. & Snakes & 25 & 24.5 \\
\hline 3. & The dark & 17 & 16.7 \\
\hline 4. & Dying or death of others & 16 & 15.7 \\
\hline 5. & Predators & 13 & 12.7 \\
\hline 6. & Strange looking people & 12 & 11.8 \\
\hline 7. & Drugs & 11 & 10.8 \\
\hline 8. & War & 10 & 9.8 \\
\hline \multirow[t]{2}{*}{9.} & Insects & 9 & 8.8 \\
\hline & Murderers & 9 & 8.8 \\
\hline 11. & Kidnapper & 8 & 7.8 \\
\hline 12. & Being teased & 7 & 6.9 \\
\hline \multirow[t]{2}{*}{13.} & Getting an injection & 6 & 5.9 \\
\hline & Violence & 6 & 5.9 \\
\hline \multirow[t]{2}{*}{15.} & Heights & 5 & 4.9 \\
\hline & Mice and rats & 5 & 4.9 \\
\hline \multirow[t]{6}{*}{17.} & Dogs & 4 & 3.9 \\
\hline & Doing something wrong & 4 & 3.9 \\
\hline & Frightening movies & 4 & 3.9 \\
\hline & Narrows & 4 & 3.9 \\
\hline & Sharks & 4 & 3.9 \\
\hline & Traffic accident & 4 & 3.9 \\
\hline \multirow[t]{8}{*}{23.} & Disasters & 3 & 2.9 \\
\hline & Fantasy creatures & 3 & 2.9 \\
\hline & Fire & 3 & 2.9 \\
\hline & Frightening dreams & 3 & 2.9 \\
\hline & Getting lost & 3 & 2.9 \\
\hline & Pets getting a serious disease & 3 & 2.9 \\
\hline & School performance or tests & 3 & 2.9 \\
\hline & The forest & 3 & 2.9 \\
\hline \multirow[t]{7}{*}{31.} & Being raped & 2 & 2.0 \\
\hline & Blood & 2 & 2.0 \\
\hline & Burglars & 2 & 2.0 \\
\hline & Getting a serious disease & 2 & 2.0 \\
\hline & Giving a talk in front of the class & 2 & 2.0 \\
\hline & Jellyfish & 2 & 2.0 \\
\hline & Scorpions & 2 & 2.0 \\
\hline \multirow[t]{12}{*}{38.} & Being punished & 1 & 1.0 \\
\hline & Crocodiles & 1 & 1.0 \\
\hline & Elevators & 1 & 1.0 \\
\hline & Going to the dentist & 1 & 1.0 \\
\hline & Losing something & 1 & 1.0 \\
\hline & Pain & 1 & 1.0 \\
\hline & Parents getting divorced & 1 & 1.0 \\
\hline & Piranhas & 1 & 1.0 \\
\hline & Rollercoasters & 1 & 1.0 \\
\hline & Slugs and snails & 1 & 1.0 \\
\hline & Telling a secret & 1 & 1.0 \\
\hline & Undergoing surgery & 1 & 1.0 \\
\hline
\end{tabular}




\section{Table 3}

Summary of fear calendar scores: Numbers of children endorsing the various response categories of frequency, duration, and intensity for each of the target fears (total $N=102$ )

\begin{tabular}{|c|c|c|c|c|c|c|c|c|}
\hline \multirow[b]{2}{*}{ Fear } & \multicolumn{3}{|l|}{ Frequency } & \multicolumn{3}{|l|}{ Duration } & \multicolumn{2}{|l|}{ Intensity } \\
\hline & Not once & $\begin{array}{l}\text { At least } \\
\text { once }\end{array}$ & $\begin{array}{l}\text { More } \\
\text { than } \\
\text { once }\end{array}$ & $\begin{array}{l}\text { Just for a } \\
\text { moment }\end{array}$ & $\begin{array}{l}\text { Less than } \\
1 \text { hour }\end{array}$ & $\begin{array}{l}\text { More } \\
\text { than } 1 \\
\text { hour }\end{array}$ & Some fear & $\begin{array}{l}\text { A lot of } \\
\text { fear }\end{array}$ \\
\hline Not being able to breathe & 96 & 6 & 0 & 6 & 0 & 0 & 6 & 0 \\
\hline Being hit by a car or truck & 94 & 6 & 2 & 6 & 1 & 1 & 7 & 1 \\
\hline Bombing attacks/being invaded & 99 & 3 & 0 & 2 & 1 & 0 & 2 & 1 \\
\hline Fire/getting burned & 95 & 7 & 0 & 4 & 2 & 1 & 5 & 2 \\
\hline Falling from high places & 90 & 11 & 1 & 11 & 1 & 0 & 8 & 4 \\
\hline
\end{tabular}

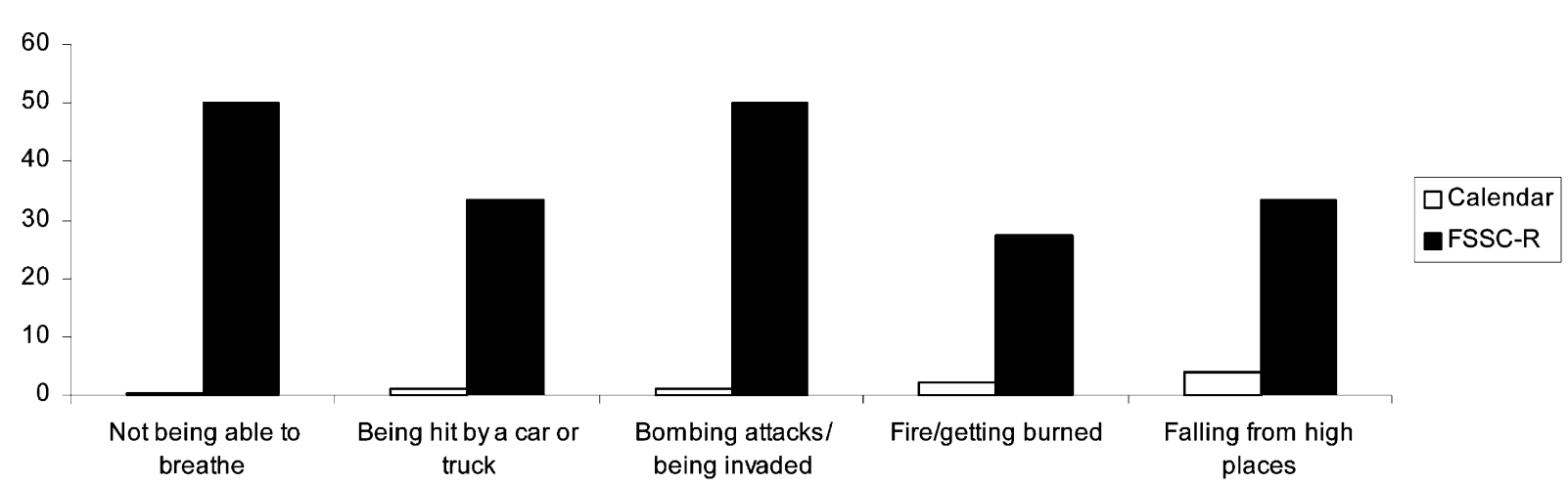

Fig. 1. Percentages of children endorsing $3=$ 'a lot of fear' to the five target fears using FSSC-R and fear calendar scores.

$Z=4.9, P<0.001$ for "Fire/getting burned", and $Z=5.1, P<0.001$ for "Falling from high places". As expected, target fears had higher frequencies when assessed with the FSSC-R than when measured with the fear calendar method.

\section{Discussion}

The current study examined the occurrence of five highly prevalent FSSC-R fears related to danger and death in a sample of unselected Dutch school children. More precisely, we studied (1) the prevalence of these target fears with a FSSC-R based fear ranking procedure, (2) the prevalence of these fears when using a fear list procedure, and (3) the occurrence of these fears in the past week using a retrospective fear calendar. As predicted, we found (a) that danger and death target fears were ranked high using the FSSC-R procedure, (b) that these fears were considerably less common when using a fear list procedure, and (c) that these target fears had a low probability of occurrence in daily life, were of short duration, and were associated with low levels of affective intensity. 
The finding that fears related to danger and death were less common when using a fear list procedure than when employing the FSSC-R is in line with earlier research. For example, in a previous study, Muris and colleagues (1997b) investigated the prevalence of childhood fears by asking children "What do you fear most?" (i.e., free option method) and then administered the FSSC-R. Results indicated that in the free option method, animal fears, in particular fear of spiders, were most frequently reported by the children, whereas fears related to danger and death were less prevalent. In contrast, when using the FSSC-R, children clearly scored highest on fears found on the danger and death factor (see for similar results Lane \& Gullone, 1999; Muris, Merckelbach, \& Collaris, 1997a). The exact meaning of these differences is difficult to determine, however. Gullone (1999) indicated that it is common for children to supply fewer items in free option methods than in survey methods, due to possible cognitive limitations of the children and/or demand characteristics inherent in these different methodologies. Accordingly, the free option method alone does not provide convincing evidence as to the prevalence or impact of these fears. For this reason, we also used a retrospective calendar method in this study to obtain more direct evidence of the occurrence and impact of these fears.

While it is the case that the retrospective fear calendar only asked for target fears in the past week, the current results support McCathie and Spence's (1991) point that frequently endorsed FSSC-R danger and death fears may have a low prevalence rate in daily life and, even when they do occur, they elicit low levels of fear. This, at least, calls into question the validity of children's high ratings on FSSC-R danger and death items. That is, it is unclear whether children are actually afraid of these items on a daily basis or whether they are reporting their perceptions of these events were they actually to occur. This point is further illustrated by the findings of a recent study by Muris, Meesters, Merckelbach et al. (in press). In that study, fear of hurricanes was measured with a single FSSC-R-like item in children who had been confronted with this natural event (i.e., Antillean children) and children who had not directly experienced this event (i.e., Belgian children). Surprisingly, it was found that Belgian children reported higher levels of fear of hurricanes than Antillean children. Muris et al. (in press) suggested that this result was due to differences in how children interpreted the fear of hurricane item. It was suggested that when Antillean children rated their level of fear of hurricanes, they likely used their own experiences with this phenomenon. In contrast, Belgian children had to rely on indirect and probably dramatized sources of information about hurricanes (e.g., seeing the consequences of a hurricane on television). In other words, when rating their fear of hurricanes, Antillean children might have replied in terms of how fearful they actually were at the time when their island was ravaged by a hurricane, whereas Belgian children might have responded in terms of how fearful one could be, or might be, were such an event to occur.

Findings of this sort illustrate that different interpretations of fear items (e.g., hurricanes) might affect the outcome of responses to fear surveys. It is clear that this observation has important implications for the assessment of fears in children. For example, a measure like the FSSC-R contains many items referring to dangerous situations that have a hypothetical status for many children. Obviously, children's ratings of such items are, in a majority of cases, not based on actual experiences with such situations and thus may reflect children's appraisal of threat in case they would be confronted with such events. This brings us back to the question originally posed by McCathie and Spence (1991): "What is the Revised Fear Survey Schedule for Children "really" measuring?" On the one hand, the FSSC-R includes items that do reflect children's actual fears 
and phobias (e.g., Weems, Silverman, Saavedra, Pina \& White Lumpkin, 1999). On the other hand, the survey also lists a number of items (in particular those related to danger and death) that probably tap perception of threat or danger. Perception of threat is more likely to be a function of children's trait anxiety levels than of children's actual fear level (see Marks, 1987). It is clear that future research should address this issue so that more specific instruments for assessing fears of children can be developed that more directly map on to the direct experiences of children and their daily lives (e.g., Gullone, King, \& Ollendick, 2000; Muris, Schmidt, Merckelbach, \& Schouten, 2001).

\section{References}

Gullone, E. (1999). The assessment of normal fear in children and adolescents. Clinical Child and Family Psychology Review, 2, 91-106.

Gullone, E., King, N. J., \& Ollendick, T. H. (2000). The development and psychometric evaluation of the Fear Experiences Questionnaire: An attempt to disentangle the fear and anxiety constructs. Clinical Psychology and Psychotherapy An International Journal of Theory and Practice, 7, 61-75.

King, N. J., Hamilton, D. I., \& Ollendick, T. H. (1988). Children's phobias: A behavioural perspective. Chichester, UK: Wiley.

King, N. J., Ollier, K., Iacuone, R., Schuster, S., Bays, K., Gullone, E., \& Ollendick, T. H. (1989). Child and adolescent fears: An Australian cross-sectional study using the Revised Fear Survey Schedule for Children. Journal of Child Psychology and Psychiatry, 30, 775-784.

Lane, B., \& Gullone, E. (1999). Common fears: A comparison of self-generated and fear survey schedule generated fears of adolescents. Journal of Genetic Psychology, 160, 194-204.

Marks, I. M. (1987). Fears, phobias, and rituals. Panic, anxiety, and their disorders. New York: Oxford University Press.

McCathie, H., \& Spence, S. H. (1991). What is the revised fear survey schedule for children actually measuring? Behaviour Research and Therapy, 29, 495-502.

Muris, P., Meesters, C., Merckelbach, H., Verschuren, M., Geebelen, E., \& Aleva, E. (in press). Fear of storms and hurricanes in Antillean and Belgian children. Behaviour Research and Therapy.

Muris, P., Merckelbach, H., \& Collaris, R. (1997a). Common childhood fears and their origins. Behaviour Research and Therapy, 35, 929-937.

Muris, P., Merckelbach, H., Meesters, C., \& Van Lier, P. (1997b). What do children fear most often? Journal of Behavior Therapy and Experimental Psychiatry, 28, 263-267.

Muris, P., Schmidt, H., \& Merckelbach, H. (2001). The structure of negative emotions in adolescents. Journal of Abnormal Child Psychology, 29, 331-337.

Ollendick, T. H. (1983). Reliability and validity of the Revised Fear Survey Schedule for Children (FSSC-R). Behaviour Research and Therapy, 21, 685-692.

Ollendick, T. H., \& King, N. J. (1994). Fears and their level of interference in adolescents. Behaviour Research and Therapy, 32, 635-638.

Ollendick, T. H., King, N. J., \& Frary, R. B. (1989). Fears in children and adolescents: Reliability and generalizability across gender, age, and nationality. Behaviour Research and Therapy, 27, 19-26.

Ollendick, T. H., Yule, W., \& Ollier, K. (1991). Fears in British children and their relationship to manifest anxiety and depression. Journal of Child Psychology and Psychiatry, 32, 321-331.

Oosterlaan, J., Prins, P. J. M., Hartman, C. A., \& Sergeant, J. A. (1995). Vragenlijst voor angst bij kinderen (VAK) Een Nederlandse bewerking van de Fear Survey Schedule for Children-Revised. Lisse, The Netherlands: Swets \& Zeitlinger.

Reynolds, C. R., \& Richmond, B. O. (1978). What I think and feel: A revised measure of children's manifest anxiety. Journal of Abnormal Child Psychology, 6, 271-280.

Sandin, B., \& Chorot, P. (1998). Dimensiones de los miedos en ninos: Estructura factorial del FSSC-R [Dimensions 
of fears in children: Factor structure of the FSSC-R]. Psiquis: Revista de Psiquiatria, Psicologia, y Psicosomatica, $19,37-46$.

Spielberger, C. D. (1973). Manual for the State-Trait Anxiety Inventory for Children. Palo Alto, CA: Consulting Psychologists Press.

Stallings, P., \& March, J. S. (1995). Assessment. In J. S. March (Ed.), Anxiety disorders in children and adolescents (pp. 125-147). Guilford Press: New York.

Weems, C. F., Silverman, W. K., Saavedra, L. M., Pina, A. A., \& White Lumpkin, P. (1999). The discrimination of children's phobias using the Revised Fear Survey Schedule for Children. Journal of Child Psychology and Psychiatry, 40, 941-952. 